\title{
UPAYA MENINGKATKAN HASIL BELAJAR PAI MATERI PUASA RAMADHAN MELALUI PENDEKATAN COOPERATIVE MODEL STAD
}

\author{
Sutami \\ Kantor Kementerian Agama Kab. Pati \\ butami333@gmail.com
}

DOI : http://doi.org/10.37730/edutrained.v5i2.120

Diterima: 29 Januari 2021 | Disetujui: 19 Desember 2021 | Dipublikasikan: 20 Desember 2021

\begin{abstract}
Abstrak
Penelitian ini bertujuan untuk meningkatkan hasil belajar PAI materi puasa ramadhan melalui pendekatan cooperative model STAD pada siswa kelas VB SDN Gabus 01. Jenis penelitiannya adalah Penelitian Tindakan Kelas. Penelitian dilaksanakan dalam tiga siklus. Setiap siklus terdiri perencanaan, pelaksanaan tindakan, observasi, dan refleksi. Tempat penelitian SD Negeri Gabus 01. Subyek penelitian siswa kelas VB yang berjumlah 27 siswa terdiri 14 siswa dan 13 siswi. Teknik pengumpulan datanya adalah teknik tes dan teknik nontes yang meliputi observasi, catatan lapangan, dan dokumentasi. Selanjutnya data dianalisis. Hasil penelitian pra siklus presentase ketuntasan hanya $41 \%$ dengan rata-rata 59,81, setelah dilakukan tindakan mengalami peningkatan. Pada siklus I mencapai $66,67 \%$ dengan rata-rata 71,15 , pada siklus II meningkat menjadi $74,08 \%$ dengan rata-rata 76,85, dan siklus III meningkat hingga 86,36\% dengan rata-rata 86,29. Berdasarkan hasil penelitian disimpulkan bahwa melalui pendekatan cooperative model STAD dapat meningkatkan hasil belajar PAI materi puasa ramadhan siswa kelas VB SDN Gabus 01 Pati.
\end{abstract}

Kata Kunci: Hasil Belajar, PAI, Pendekatan Cooperative, STAD

\begin{abstract}
This study aims to improve the learning outcomes of Islamic Education in Ramadhan fasting material through the cooperative approach of the STAD model in class VB SDN Gabus 01. The type of research is classroom action research. The research was conducted in three cycles. Each cycle consists of planning, implementing the action, observing, and reflecting. The research location SD Negeri Gabus 01. The subjects of the research were 27 students of class VB consisting of 14 students and 13 students. The data collection techniques are test techniques and non-test techniques which include observation, field notes, and documentation. Then the data were analyzed. The results of pre-cycle research, the percentage of completeness were only $41 \%$ with an average of 59.81, after the action had increased. In the first cycle it reached $66.67 \%$ with an average of 71.15 , in the second cycle it increased to $74.08 \%$ with an average of 76.85, and the third cycle increased to $86.36 \%$ with an average of 86.29 . Based on the results of the study, it was concluded that through the cooperative approach, the STAD model could improve the learning outcomes of Islamic Education in the Ramadhan fasting material for the fifth grade students of SDN Gabus 01 Pati.
\end{abstract}

Keywords: Learning Outcomes, Islamic Education, Cooperative Approach, STAD 


\section{PENDAHULUAN}

Pendidikan Agama Islam di Sekolah Dasar hendaknya mendukung pencapaian kompetensi dasar yang meliputi : nilai pengetahuan, nilai sikap, dan kemampuan melaksanakan tugas atau kemampuan untuk mendekatkan dirinya dengan lingkungan alam, lingkungan sosial, lingkungan budaya dan kebutuhan daerah. Seorang guru hendaknya mempunyai kemampuan yang harus dimiliki seorang guru/pendidik (Darmadi, 2015). Menurut Suharsimi Arikunto ada tiga kemampuan penting yang harus dimiliki oleh seorang guru yang profesional yaitu (1) kompetensi profesional, (2) kompetensi personal, dan (3) kompetensi sosial (Arikunto, 2018). Adapun yang dimaksud dengan kompetensi adalah "Pengetahuan, keterampilan dan nilai-nilai dasar yang direfleksikan dalam kebiasaan berfikir dan bertindak, dalam arti memiliki pengetahuan keterampilan dan nilai-nilai dasar untuk melakukan sesuatu" (Habibullah, 2012). Dengan kompetensi-kompetensi tersebut seorang guru akan mampu menguasai model dan tehnik pembelajaran yang menarik, yang menjadikan siswa senang, nyaman dan antusias dalam pembelajaran, sehingga dapat membuahkan hasil yang sejalan dengan fungsi dan tujuan pendidikan. Selain itu guru dituntut dapat membangkitkan motivasi belajar pada siswa (Arianti, 2019). Usaha yang dapat dilakukan untuk dapat meningkatkan motivasi belajar siswa, guru dapat menggunakan salah satu model pembelajaran inovatif sehingga siswa menikmati kegiatan pembelajaran.

Pada kenyataannya di Sekolah Dasar saat ini, Pendidikan Agama Islam menunjukkan indikasi bahwa pola pembelajarannya masih bersifat teacher centered (berpusat pada guru)
(Antika, 2014). Kecenderungan pembelajaran demikian, mengakibatkan lemahnya pengembangan potensi diri siswa dalam pembelajaran sehingga prestasi belajar yang dicapai tidak optimal. Kesan menonjolnya verbalisme dalam pelaksanaan kegiatan belajar mengajar di kelas masih terlalu kuat. Suasana belajar yang bersifat teacher centered (berpusat pada guru) itu, semakin menjauhkan peran Pendidikan Agama Islam dalam upaya mempersiapkan warga negara yang baik dan memasyarakat.

Pembelajaran PAI materi puasa ramadhan memerlukan pemahaman yang sangat serius. Karena materi puasa ramadhan sangat penting dalam keberagamaan siswa. Puasa ramadhan adalah salah satu rukun Is;am yang wajib dilaksanakan setiap muslim baik lakilaki maupun perempuan. Merupakan ibadah fardhu bagi setiap muslim beriman yang telah memenuhi ketentuan dalam syara, diantaranya sudah akil baligh. Sebagaimana firman

Allah dalam surah Al baqoroh ayat 183 berikut:

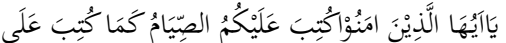

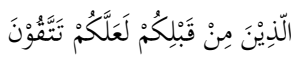

Artinya: "Wahai orang-orang yang beriman! Diwajibkan atas kamu berpuasa sebagaimana diwaibkan atas orang-orang sebelum kamu agar kamu bertaqwa." (Q.S. AlBaqoroh: 183).

Karena begitu pentingnya materi puasa ramadhan, maka dibutuhkan model pembelajaran yang menjadikan siswa nyaman dan menyenangkan dengan harapan siswa dapat memahami materi untuk diimplementasikan dalam kehidupan 
keberagamaan dan meningkatkan hasil belajarnya.

Namun pada kenyataannya, berdasarkan pengalaman pribadi penulis, keadaan siswa kelas VB SD Negeri Gabus 01, kecamatan Gabus, kabupaten Pati belum mampu memahami materi puasa ramadhan. Hal ini disebabkan guru dalam memilih model pembelajaran belum tepat. Pola pembelajarannya masih bersifat teacher centered (berpusat pada guru). Kecenderungan pembelajaran demikian, mengakibatkan lemahnya pengembangan potensi diri siswa dalam pembelajaran sehingga prestasi belajar yang dicapai tidak optimal. Hasil belajar materi puasa ramadhan masih rendah. Terbukti dengan ketuntasan hasil belajar dari 27 siswa yang tuntas baru 11 siswa. Setelah dianalisis prosentase ketuntasan klasikal $41 \%$ dan rata-rata kelas 59,81 . Belum mencapai tarjet KKM yang ditentukan yakni sekurangkurangnya $75 \%$.

Pendekatan cooperative model Student Teams Achievement Division (STAD) adalah salah satu sekian banyak model-model pembelajaran untuk meningkatkan hasil belajar siswa. Dengan pendekatan cooperative model Student Teams Achievement Division (STAD) pembelajaran tidak terkesan monoton, siswa tidak akan bosan, mereka akan lebih aktif dan lebih antusias dalam mengikuti pembelajaran PAI (Wyk, 2012). Dengan demikian diharapkan akan tercapai tujuan pembelajaran dengan maksimal.

Berpijak pada fakta di atas, maka peneliti menerapkan pendekatan cooperative model Student Teams Achievement Division (STAD) untuk meningkatkan hasil belajar siswa kelas VB pada pembelajaran PAI materi puasa ramadhan. Selanjutnya peneliti menyusun laporan dengan mengangkat judul "Upaya Meningkatkan Hasil Belajar PAI Materi Puasa Ramadhan melalui Pendekatan Cooperative Model Student Teams Achievement Division (STAD) pada Siswa Kelas VB SD Negeri Gabus 01 Pati Tahun Pelajaran 2019/2020.

Rumusan masalah dalam penelitian ini adalah: (1). Bagaimana penerapan pendekatan cooperative model Student Teams Achievement Division (STAD) pada mata pelajaran PAI materi Puasa Ramadhan kelas VB SD Negeri Gabus 01 Pati tahun pelajaran 2019/2020? (2). Apakah melalui pendekatan cooperative model Student Teams Achievement Division (STAD) dapat meningkatkan hasil belajar PAI materi materi puasa ramadhan pada siswa kelas VB SD Negeri Gabus 01 Pati tahun pelajaran 2019/2020?

Tujuan penelitian ini adalah (1). Untuk mengetahui proses penerapan pendekatan cooperative model Student Teams Achievement Division (STAD) pada mata pelajaran PAI materi puasa ramadhan kelas VB SD Negeri Gabus 01 Pati tahun pelajaran 2019/2020? (2). Untuk meningkatkan hasil belajar PAI pelajaran PAI materi puasa ramadhan melalui pendekatan cooperative model Student Teams Achievement Division (STAD) pada siswa kelas VB SD Negeri Gabus 01 Pati tahun pelajaran 2019/2020?

Manfaat Penelitian ini adalah: 1) Manfaat Teoritis: mendapatkan pengetahuan atau teori baru tentang peningkatan hasil belajar PAI materi puasa ramadhan melalui pendekatan cooperative model Student Teams Achievement Division (STAD) pada siswa kelas VB SD Negeri Gabus 01 
Pati tahun pelajaran 2019/2020? 2) Manfaat Praktis: Siswa lebih mudah memahami materi yang disampaikan dan dapat meningkatkan hasil belajarnya. Guru dapat meningkatkan kreatifitas untuk mencapai pembelajaran yang berkualitas. Sekolah memperoleh informasi ilmiah tentangberbagai model pembelajaran aktif, kreatif dan inovatif untuk meningkatkan kwalitas sekolah.

\section{LANDASAN TEORI}

Belajar merupakan suatu proses perubahan dari belum bisa menjadi bisa, dari bisa menjadi lebih bisa. Menurut Budiningsih "Belajar merupakan suatu proses internal yang mencakup ingatan, retensi, pengolahan, informasi, emosi dan aspek-aspek kejiwaan lainnya" (Budiningsih, 2005). Belajar merupakan aktifitas yang melibatkan proses berfikir yang sangat kompleks. Proses belajar terjadi antara lain mencakup pengaturan stimulus yang diterima dan menyesuaikannya dengan struktur kognitif yang sudah dimiliki dan terbentuk di dalam pikiran seseorang berdasarkan pemahaman dan pengalamanpengalaman sebelumnya. Sedangkan menurut Slameto belajar adalah suatu proses usaha yang dilakukan seseorang untuk memperoleh perubahan tingkah laku yang baru secara keseluruhan, sebagai hasil pengalamannya sendiri dalam interaksi dengan lingkungannya (Slameto, 2003). Arsyad berpendapat bahwa belajar diartikan sebagai suatu proses kompleks yang terjadi pada diri setiap orang sepanjang hidupnya (Arsyad, 2013). Proses belajar itu terjadi karena adanya interaksi seseorang dengan lingkungannya. Oleh karena itu, belajar dapat terjadi kapan saja dan di mana saja. Jadi kesimpulannya belajar adalah merupakan suatu aktivitas dan perubahan perilaku manusia seperti kebiasaan, pengetahauan, sikap, keterampilan, dan daya pikir yang memperoleh informasi baru sehingga membentuk kepribadian manusia tersebut.

Hasil Belajar merupakan keadaan atau perubahan setelah adanya proses. Menurut Suprijono, hasil belajar adalah perubahan perilaku tidak hanya satu aspek potensi kemanusiaan saja melainkan secara keseluruhan atau komprehensif (Suprijono, 2011). Hasil belajar juga diartikan oleh Arikunto (1990: 133), sebagai hasil akhir setelah mengalami proses belajar, perubahan itu tampak dalam perbuatan yang dapat diaamati, dan dapat diukur (Arikunto, 2018). Klasifikasi hasil belajar menurut Bloom dalam Sudjana, membagi hasil belajar ke dalam tiga ranah yakni ranah kognitif, ranah afektif, dan ranah psikomotoris (Sudjana, 2013). Ranah Kognitif berkenaan dengan hasil belajar intelektual yang terdiri dari 6 aspek yaitu pengetahuan, pemahaman, penerapan, analisis, sintesis dan penilaian. Ranah Afektif berkenaan dengan sikap dan nilai. ranah afektif meliputi lima jenjang kemampuan yaitu menerima, menjawab atau reaksi, menilai, organisasi dan karakterisasi dengan suatu nilai atau kompleks nilai. Ranah Psikomotor meliputi: keterampilan motorik, manipulasi benda-benda, koordinasi neuromuscula (menghubungkan, mengamati). Hasil belajar yang merupakan kemampuankemampuan yang dimiliki peserta didik setelah mereka menerima pengalaman belajarnya, digunakan oleh guru untuk dijadikan ukuran atau kriteria dalam mencapai suatu tujuan pendidikan. Hal ini dapat tercapai apabila peserta didik sudah 
memahami belajar dengan diiringi oleh perubahan tingkah laku yang lebih baik lagi.

Menurut Dalyono berhasil tidaknya seseorang dalam belajar disebabkan oleh dua faktor yaitu: a. Faktor Intern (yang berasal dari dalam diri orang yang belajar) yang meliputi: (1) kesehata jasmani dan rohani yang sangat besar pengaruhnya terhadap kemampuan belajar; (2) Intelegensi dan Bakat; (3) minat dan Motivasi, minat dapat timbul karena adanya daya tarik dari luar dan juga datang dari sanubari; dan (4) Cara belajar. Cara belajar seseorang juga mempengaruhi pencapaian hasil belajarnya (Dalyono, 1997). Belajar tanpa memperhatikan teknik dan faktor fisiologis, psikologis, dan ilmu kesehatan akan memperoleh hasil yang kurang.

Faktor belajar ini digunakan untuk memahami karakteristik siswa dan untuk mengetahui keadaan lingkungan sekitar serta sarana pra sarana yang ada, agar tidak salah dalam menerapkan suatu metode pembelajaran. Dengan memahami factor belajar yang ada dimaksudkan untuk melaksanakan proses pembelajaran yang berlangsung dalam suasana yang menyenangkan dan mengesankan. Hal ini diterapkan agar proses pembelajaran lebih bermakna dan siswa lebih mudah menguasai dan memahami kompetensi-kompetensi dalam pembelajaran

Pendidikan Agama Islam merupakan ilmu yang mempelajari tentang agama Islam yang bersifat universal yang bersumber pada Alqur'an dan Hadits, disamping sumber-sumber yang lain. Menurut Ahmadi, Pendidikan Agama Islam merupakan adalah segala usaha untuk memelihara fitrah manusia, serta sumber daya insani yang ada padanya menuju terbentuknya manusia seutuhnya sesuai norma Islam (Achmadi, 2005). Sedangkan menurut Zakiah Daradjat dalam Abdul Majid dan Dian A, Pendidikan Agama Islam adalah Suatu usaha untuk membina dan mengasuh peserta didik agar senantiasa dapat memahami ajaran agama Islam secara menyeluruh, lalu menghayati tujuan, yang pada akhirnya dapat mengamalkan serta menjadikan Islam sebagai pandangan hidup (Majid \& Andriani, 2004). Zuhairini berpendapat bahwa Pendidikan Agama Islam adalah usaha-usaha secara sistematis dan pragmatis dalam membantu anak didik agar mereka hidup sesuai dengan ajaran Islam (Zuhairini, 1983). Jadi Pendidikan Agama Islam adalah upaya sadar dan terencana untuk memelihara fitrah manusia dan menyiapkan peserta didik untuk mengenal, memahami, menghayati, bertaqwa dan berakhlak mulia dalam mengamalkan ajaran Islam dari sumber utamanya kitab suci AlQur'an dan hadits, melalui kegiatan bimbingan, latihan, pengamalan dibarengi tuntunan untuk menghormati penganut agama lain dalam hubungannya dengan kerukunan antar umat beragama dalam masyarakat hingga terwujud kesatuan dan persatuan bangsa dan menuju terbentuknya manusia seutuhnya sesuai norma Islam.

Dapat disimpulkan bahwa hasil belajar PAI adalah perubahan perilaku dalam seluruh aspek, untuk memelihara fitrah manusia menuju terbentuknya manusia seutuhnya sesuai norma Islam. Pendidikan Agama Islam di tingkat $\mathrm{SD} / \mathrm{Mi}$ memiliki beberapa tujuan. Menurut Kemdikbud, Pendidikan Agama Islam di SD/MI bertujuan untuk: menumbuhkembangkan akidah 
melalui pemberian, pemupukan, dan pengembangan pengetahuan, penghayatan, pengamalan, pembiasaan, serta pengalaman peserta didik tentang agama Islam sehingga menjadi manusia muslim yang terus berkembang keimanan dan ketakwaannya kepada Allah SWT; mewujudkan manuasia Indonesia yang taat beragama dan berakhlak mulia yaitu manusia yang berpengetahuan, rajin beribadah, cerdas, produktif, jujur, adil, etis,berdisiplin, bertoleransi (tasamuh), menjaga keharmonisan secara personal dansosial serta mengembangkan budaya agama dalam komunitas sekolah (Kemdikbud, 2003).

Ruang lingkup Pendidikan Agama Islam meliputi keserasian, keselarasan, dan keseimbangan antara hubungan manusia dengan Allah SWT, hubungan manusia dengan sesama manusia, dan ketiga hubungan manusia dengan dirinya sendiri, serta hubungan manusia dengan makhluk lain dan lingkungannya. Ruang lingkup pendidikan agama Islam juga identik dengan aspek-aspek pengajaran agama Islam karena materi yang terkandung didalamnya merupakan perpaduan yang saling melengkapi satu dengan yang lainnya.

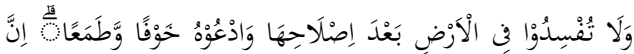

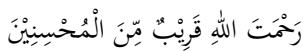

Artinya : "Dan janganlah kamu membuat kerusakan di muka bumi, sesudah (Allah) memperbaikinya dan berdoalah kepada-Nya dengan rasa takut (Tidak akan diterima) dan harapan (akan dikabulkan). Sesungguhnya rahmat Allah amat dekat kepada orang-orang yang berbuat baik". (surat al A'raaf : 56 ).
Pada dasarnya pembelajaran Pendidikan Agama Islam meliputi lima unsur pokok yaitu Al Quran dan Al Hadis, Aqidah, Akhlak, Fiqih dan Tarikh. Dan Kebudayaan Islam adalah salah satu aspek mata pelajaran Pendidikan Agama Islam pada Sekolah Dasar untuk memberikan motivasi, membimbing, mengarahkan pemahaman, serta mengembangkan kemampuan dasar dan penghayatan isi Alquran yang diharapkan dapat diwujudkan dalam perilaku seharihari yang memancarkan iman dan taqwa kepada Allah SWT sesuai dengan ketentuan Al Quran Hadis. Pembelajaran kooperatif (cooperativ learning) dapat diartikan sebagai belajar kelompok. Menurut Anita Lie, pembelajaran kooperatif (cooperativ learning) adalah strategi/pendekatan pembelajaran yang menggunakan kelompok kecil siswa untuk bekerjasama dalam rangka memaksimalkan kondisi belajar untuk mencapai tujuan belajar (Lie, 2008). Sedangkan menurut Slavin dalam Yan Vita, model pembelajaran kerjasama (cooperative learning) salah satumya dikembangkan oleh Robert E, Slavin. Cooperative Learning diartikan sebagai suatu model belajar mengajar yang menekankan pada sikap atau perilaku kerjasama atau saling membantu diantara sesama dalam sebuah kelompok yang terdiri dua orang atau lebih (Vita, 2014). Cooperative learning disebut juga dengan pembelajaran gotong royong, yaitu sistem pembelajaran yang memberi kesempatan kepada peserta didik untuk bekerjasama dengan siswa lain dalam tugas-tugas yang terstruktur (Novita Eka Indiyani, 2006). Pembelajaran kooperatif berbeda dengan strategi pembelajaran yang lain. Perbedaan tersebut dapat dilihat dari proses 
pembelajaran yang lebih menekankan kepada proses kerjasama dalam kelompok. Adapun karakteristik dari pembelajaran kooperatif adalah :pembelajaran secara tim, idasarkan pada manajemen kooperatif, serta ada kemauan dan keterampilan bekerja sama. Pembelajaran cooperative bisa digunakan dalam beberapa mata pelajaran bahkan hampir semua mata pelajaran (Slavin, 1980), diantaranya Matematika, Pendidikan Agama Islam, IPS, IPA, dan Bahasa.

Sedangkan Student Teams Achievement Division (STAD) adalah salah satu model pembelajaran terkini yang menjadikan siswa aktif dalam pembelajaran. Ricard I., Arends berpendapat bahwa Student Teams Achievement Division (STAD) adalah metode dari pendekatan Cooperatibe learning bahwa siswa bekerja dikelompok-kelompok dengan kemampuan campuran dan reward diadministrasikan dan diakui untuk usaha individual maupun kelompok) (Arends, 2008).

$$
\text { Anita E. Woolfolk }
$$

mengemukakan bahwa Student Teams Achievement Division (STAD) adalah Pembelajaran kooperatif dengan kelompok heterogen dan unsur kompetisi dan penghargaan (Woolfolk, 2001). Masing-masing grup mempunyai sekitar lima anggota dengan campuran kemampuan, latar belakang kesukuan dan jenis kelamin. Guru mengkalkulasi tujuan belajar perorangan, mencetak prestasi, score dasar, anggota regu. Score ini membuat tingkat pencapaian ratarata siswa. Para siswa bekerja dalam regu mereka untuk belajar dan bersiap-siap menghadapi dua kali kuis, tetapi mereka mengambil kuis secara individu seperti halnya dalam suatu kelas reguler. Berdasarkan keberhasilan test yang dicapai masing-masing anggota regu dapat membimbing satu sampai tiga poin untuk kelompok lain.

$$
\text { Menurut }
$$

Saminanto,

Penerapan metode Student Teams Achievement Division (STAD) terdiri atas siklus pembelajaran yang membawa siswa pada suasana kerja sama (Saminanto, 2010). langkahlangkah kegiatan pembelajaran tersebut adalah:

membentuk kelompok yang anggotanya 5 orang secara heterogen (campuran menurut prestasi, jenis kelamin, suku, dll), guru menyajikan pelajaran, guru memberi tugas kepada kelompok untuk dikerjakan oleh anggota-anggota kelompok. Anggotanya yang sudah mengerti dapat menjelaskan pada anggota lain sampai semua anggota dalam kelompok itu mengerti, guru memberi kuis/pertanyaan kepada seluruh siswa. Pada saat menjawab kuis tidak boleh saling bantu, guru memberi evaluasi, dan menyimpulkan.

\begin{tabular}{llr}
\multicolumn{1}{c}{ Metode } & Student & Teams \\
Achievement & Division & (STAD) \\
dibanding & dengan & metode
\end{tabular}
pembelajaran lain mempunyai banyak kelebihan diantaranya membantu siswa mempelajari isi materi pelajaran, adanya kerja kelompok yang menghindari kemungkinan siswa mendapat nilai rendah, adnya diskusi yang menjadikan siswa mampu belajar mengungkapkan argumen, belajar mendengarkan pendapat orang lain, meningkatkan harga diri siswa dan memperbaiki hubungan dengan teman sebaya, juga adanya reword yang diberikan akan memberikan dorongan bagi siswa untuk mencapai hasil yang lebih tinggi, siswa yang lambat berpikir dapat dibantu oleh anggota kelompok yang lain, serta pembentukan kelompok-kelompok kecil memudahkan guru untuk memonitor siswa dalam belajar bekerja sama. 
Kelebihan-kelebihan metode ini sangat membantu dan besar pengaruhnya terhadap penguasaan kompetensi-kompetensi pembelajaran. Metode Student Teams Achievement Division (STAD) yang dalam pelaksanaannya mendorong siswa untuk berdiskusi, saling bantu menyelesaikan tugas pada akhirnya siswa dapat menguasai kompetensikompetensi pembelajaran dan mampu menerapkan ketrampilan yang diberikan. Dengan siswa mampu menguasai kompetensi-kompetensi pembelajaran dan mampu menerapkan ketrampilan yang diberikan, maka akan berpengaruh terhadap peningkatan hasil belajar siswa.

Dengan memahami dan mengetahui model pembelajaran coperative learning model Student Teams Achievement Division (STAD) ini, maka guru akan dapat merubah paradigma mengajar dari konvensional kepada model pembelajaran yang dapat memotivasi siswa untuk aktif, kreatif, inovatif dan menyenangkan.

Penelitian yang terkait adalah (1) Penelitian Anisa Riski tahun 2018 (skripsi) dengan judul:"Penerapan Model pembelajaran Kooperatif tipe STAD dalam Meningkatkan Hasil Belajar Siswa pada Mata Pelajaran PKN di SDN Tulusrejo Kecamatan Pekalongan tahun 2018". Bahwa hasil penelitian menunjukkan hasil belajar siswa meningkat pada setiap siklus setelah diterapkan pembelajaran kooperatif tipe STAD. Pada siklus pertama siswa yang tuntas mencapai $50 \%$. Di siklus kedua meningkat hingga mencapai $72,22 \%$. Dengan demikian penerapan model pembelajaran kooperatif tipe STAD pada mata pelajaran PKN dikatakan berhasil dalam meningkatkan hasil belajar siswa. (2) Penelitian Septiana
Idyani tahun 2019 dengan judul:"Penerapan Model Pembelajaran Kooperatif Tipe STAD untuk Meningkatkan Hasil Belajar Matematika Materi penyajian Data pada Siswa Kelas VIIC SMPN 3 Getasan Kabupaten Semarang Tahun Pelajaran 2018/2019". Hasil penelitian menunjukkan hasil belajar siswa meningkat. Dari pra siklus sebelum tindakan yang mencapai KKM 26,08\%, pada siklus I setelah ada tindakan meningkat menjadi 69,56\%. Pada siklus II siswa yang tuntas meningkat hingga mencapai 91,31\%. Dengan demikian penerapan model pembelajaran kooperatif tipe STAD berhasil meningkatkan hasil belajar matematika materi penyajian data.

\section{METODE PENELITIAN}

Jenis penelitian pada penelitian ini adalah Penelitian Tindakan Kelas (PTK). Menurut Sutama, Penelitian Tindakan Kelas merupakan upaya untuk memperbaiki praktik pembelajaran agar menjadi efektif. Karakterisitik PTK secara garis besar adalah: 1) Mengkaji permasalahan situasiona dan kontekstual, 2) adanya tindakan, 3) adanya evaluasi terhadap tindakan, 4) pengkajian terhadap tindakan, 5) adanya kerjasama, dan 6) adanya refleksi (Sutama, 2011). Waktu Penelitian Tindakan Kelas ini dilakukan selama empat bulan yaitu mulai bulan Agustus sampai November 2019.

Tempat penelitian dilakukan di SD Negeri Gabus 01 Kecamatan Gabus Kabupaten Pati tepatnya di kelas VB. Peneliti memilih tempat di kelas VB karena tempat permasalahan terjadi di kelas tersebut dan peneliti bertugas sebagai guru PAI di kelas tersebut juga. Penelitian Tindakan Kelas ini dilakukan selama tiga bulan yaitu mulai bulan Agustus sampai 
bulan Oktober 2019. Subjek penelitian dalam Penelitian Tindakan Kelas ini sejumlah siswa kelas VB SD Negeri Gabus $01 \quad$ Kecamatan Gabus Kabupaten Pati Semester I tahun ajaran 2019/2020. Adapun jumlah siswa kelas VB Sekolah Dasar Negeri Gabus 01 Kecamatan Gabus Kabupaten Pati berjumlah 27 siswa yang terdiri dari 14 siswa laki -laki dan 13 siswa perempuan, dengan tingkat kecerdasan yang berbedabeda. Sebagian besar mereka berasal dari keluarga dengan ekonomi menengah ke atas. Akan tetapi mereka masih banyak yang belum mau untuk sekolah diniyah maupun di Taman Pendidikan Al-Qur`an (TPQ). Mereka lebih mengedepankan pengetahuan umum. Orang tua lebih menekankan putra-putrinya untuk les privat mata pelajaran umum, sehingga waktunya dihabiskan untuk belajar ilmu duniawi. Akibatnya pengetahuan keagamaan belum mencapai harapan. Pelajaran Pendidikan Agama Islam dan Budi Pekerti seakan dikesampingkan.

Sumber data penelitian ini diambil dari: siswa sebagai subyek penelitian dan dokumen. Adapun data yang dikumpulkan dalam penelitian ini adalah data hasil belajar dan unjuk kerja siswa yang diambil dari hasil tes pada akhir siklus dan data hasil observasi KBM.

Teknik dan Instrumen Penilaian. Tehnik pengumpulan data pada penelitian ini dengan test dan non test. Teknik test dilakukan dengan test penilaian harian, sedang teknik non test dilaksanakan dengan melakukan pengamatan (observasi). Teknik observasi dilakukan untuk mengetahui keaktifan siswa dalam proses pembelajaran materi puasa ramadhan pada mata pelajaran PAI kelas VB SD Negeri Gabus 01. Alat pengumpulan data dalam penelitian ini melalui: instrumen lembar penilaian dan instrumen lembar pengamatan. Instrumen yang digunakan dalam penelitian ini terdiri dari: (1) silabus yaitu seperangkat rencana dan pengaturan tentang kegiatan pembelajaran pengelolahan kelas, serta penilaian hasil belajar; (2) Rencana Pelaksanaan Pembelajaran (RPP) yaitu merupakan perangkat pembelajaran yang digunakan sebagai pedoman guru dalam mengajar dan disusun untuk tiap putaran. Masingmasing RPP berisi kompetensi dasar, indicator pencapaian hasil belajar, tujuan pembelajaran khusus, dan kegiatan belajar mengajar; (3) Lembar Kegiatan Siswa yang dipergunakan siswa untuk membantu proses pengumpulan data hasil eksperimen; (4) Lembar Observasi Kegiatan Belajar Mengajar yang terdiri lembar observasi pengolahan metode mengajar beregu, untuk mengamati kemampuan guru dalam mengelola pembelajaran dan lembar observasi aktivitas siswa dan guru, untuk mengamati aktivitas siswa dan guru selama proses pembelajaran; (5) Tes formatif yang disusun berdasarkan tujuan pembelajaran yang akan dicapai. Tes formatif ini diberikan setiap akhir putaran. Bentuk soal yang diberikan adalah pilihan ganda (objektif).

Validasi data mencerminkan prestasi belajar siswa dianalisis dari perolehan nilai pra siklus, siklus 1 , siklus 2 dan siklus 3 . Perolehan nilai tiap siklus tersebut kemudian dibandingkan untuk menentukan tingkat peningkatan hasil belajar yang dicapai setelah pelaksanan pendekatan cooperative metode Student Teams Achievement Division (STAD. Sedangkan validitas data untuk mengetahui peningkatan proses belajar dianalisis secara kualitatif yaitu dari hasil observasi. 


\section{HASIL PENELITIAN \\ PEMBAHASAN \\ Hasil Penelitian}

Hasil belajar merupakan suatu perubahan pada diri individu. Menurut Nana Sudjana, perubahan yang dimaksud dalam belajar tidak hanya perubahan pengetahuan, tetapi juga meliputi perubahan kecakapan, sikap, pengertian, dan penghargaan diri pada individu tersebut (Sudjana, 2013). Dari hasil analisis, hasil belajar materi PAI Puasa Ramadhan kelas VB dikatakan belum berhasil karena siswa yang belum tuntas di atas $50 \%$ yaitu 59 \%. Hal ini disebabkan pembelajaran masih berpusat pada guru (teacher centered). Guru belum memanfaatkan model pembelajaran yang inovatif dan tepat guna. Sehingga siswa merasa jenuh, tidak bersemangat dalam mengikuti pembelajaran. Siswa cenderung duduk, dan mendengakan penjelasan guru. Hasil belajar siswa rendah. Dari 27 siswa yang tuntas secara individu baru 11 siswa (41\%), siswa yang lain yakni 16 siswa (59\%) belum tuntas. Nilai rata-rata pada pra tindakan adalah 59,81. Berikut tabel analisis hasil belajar sebelum tindakan (pra siklus).

Tabel 1

Hasil Analisis Tes Formatif Pembelajaran Awal

\begin{tabular}{clc}
\hline No. & Indikator & Keterangan \\
\hline 1. & Nilai terendah & 40 \\
2. & Nilai tertinggi & 90 \\
3. & Jumlah nilai & 1555 \\
4. & $\begin{array}{l}\text { Rata - rata nilai tes } \\
\text { formatif }\end{array}$ & 59,81 \\
5anyaknya siswa & yang memperoleh & 11 \\
nilai $\geq 75$ & \\
6. & $\begin{array}{l}\text { Prosentase siswa } \\
\text { yang memperoleh }\end{array}$ & $41 \%$
\end{tabular}

\begin{tabular}{clc}
\hline No. & Indikator & Keterangan \\
\hline & nilai $\geq 75$ & \\
Banyaknya siswa & \\
7. & $\begin{array}{l}\text { yang memperoleh } \\
\text { nilai }<75\end{array}$ & 16 \\
8. & $\begin{array}{l}\text { Prosentase siswa } \\
\text { dengan nilai }<75\end{array}$ & $59 \%$ \\
\hline
\end{tabular}

Dari dari tabel tersebut tampak siswa yang nilainya kurang dari 75 adalah 16 siswa. Artinya siswa yang belum tuntas lebih banyak.

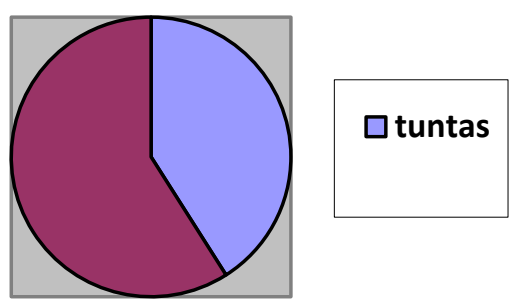

Gambar 1. Prosentase Ketuntasan Pembelajaran Pra Siklus

Dari diagram di atas menunjukan bahwa prosentase siswa yang tuntas lebih sedikit (41\%) dibanding siswa yang tidak tuntas (59\%). Kemudian Peneliti melaksanakan Penelitian Tindakan Kelas dengan menerapkan pendekatan cooperative model Student Teams Achievement Division (STAD) yang terdiri dari perencanaan, pelaksanaan, observasi dan refleksi. Penelitian yang dilaksanakan terdiri dari tiga siklus. Hasil penelitian observasi aktivitas siswa disajikan dalam bentuk data kualitatif dan data deskriptif, sedangkan hasil belajar siswa disajikan dalam bentuk data kuantitatif. Siklus 1 dilaksanakan pada hari Kamis, 12 Oktober 2019 pada jam ke-1 sampai ke-3 yakni 07.00-08.45. 
Tabel 2

Analisis Hasil Belajar Siklus I

\begin{tabular}{clcc}
\hline No & Pencapaian & $\begin{array}{c}\text { Data } \\
\text { Awal }\end{array}$ & $\begin{array}{c}\text { Data } \\
\text { Siklus 1 }\end{array}$ \\
\hline 1. & Rata - rata & 59,81 & 71,15 \\
2. $\begin{array}{l}\text { Nilai } \\
\text { terendah }\end{array}$ & 40 & 50 \\
3. $\begin{array}{l}\text { Nilai } \\
\text { tertinggi }\end{array}$ & 90 & 90 \\
4. $\begin{array}{l}\text { Jumlah } \\
\text { belum tuntas }\end{array}$ & 16 siswa & 9 siswa \\
5. $\begin{array}{l}\text { Jumlah } \\
\text { tuntas }\end{array}$ & 11 siswa & 18 siswa \\
6. $\begin{array}{l}\text { Prosentase } \\
\text { belum tuntas }\end{array}$ & $59 \%$ & $32,33 \%$ \\
7. $\begin{array}{l}\text { Prosentase } \\
\text { tuntas }\end{array}$ & $41 \%$ & $66,67 \%$ \\
\hline
\end{tabular}

Berdasarkan data tabel hasil analisis tes siklus I diketahui bahwa rata-rata awal sebelum pelaksanaan siklus adalah 59.81. Setelah dilaksanakan siklus I diperoleh data nilai rata-rata 71,15 . Hasil tersebut menunjukkan bahwa pada siklus pertama secara klasikal siswa belum tuntas belajar, karena siswa yang memperoleh nilai $\geq 75$ hanya sebesar $66,67 \%$ lebih kecil dari persentase ketuntasan yang dikehendaki yaitu sebesar 75\%. Hal ini disebabkan karena siswa masih merasa baru dan belum mengerti apa yang dimaksudkan dan digunakan guru dengan menerapkan metode metode mengajar beregu.

$$
\text { Karena tujuan belum }
$$
terealisasikan, maka diadakan siklus II. Siklus II dilaksanakan hari Kamis, 19 Oktober 2019 pada jam ke-1 sampai jam ke-3 yakni mulai pukul 07.00 sampai dengan pukul 08.45 WIB. Berilkut tabel analisis hasil belajar siklus II
Tabel 3

Hasil Analisis Tes Siklus II

\begin{tabular}{|c|c|c|c|}
\hline No & Pencapaian & $\begin{array}{c}\text { Data } \\
\text { Siklus I }\end{array}$ & $\begin{array}{c}\text { Data } \\
\text { Siklus II }\end{array}$ \\
\hline 1. & Rata - rata & 70,15 & 76,85 \\
\hline 2. & $\begin{array}{l}\text { Nilai } \\
\text { terendah }\end{array}$ & 50 & 60 \\
\hline 3. & $\begin{array}{l}\text { Nilai } \\
\text { tertinggi }\end{array}$ & 90 & 95 \\
\hline 4. & $\begin{array}{l}\text { Jumlah } \\
\text { belum tuntas }\end{array}$ & 9 siswa & 7 siswa \\
\hline 5. & $\begin{array}{l}\text { Jumlah } \\
\text { tuntas }\end{array}$ & 18 siswa & 20 siswa \\
\hline 6. & $\begin{array}{l}\text { Prosentase } \\
\text { belum tuntas }\end{array}$ & $32,33 \%$ & $25,92 \%$ \\
\hline 7. & $\begin{array}{l}\text { Prosentase } \\
\text { tuntas }\end{array}$ & $66,67 \%$ & $74,08 \%$ \\
\hline
\end{tabular}

Dari tabel di atas diperoleh nilai rata-rata prestasi belajar siswa adalah 76,85 dan ketuntasan belajar mencapai $74,08 \%$ atau ada 20 siswa dari 27 siswa sudah tuntas belajar. Hasil ini menunjukkan bahwa pada siklus II ini ketuntasan belajar secara klasikal telah megalami peningkatan sedikit lebih baik dari siklus I meskipun belum memenuhi harapanl Adanya peningkatan hasil belajar siswa ini karena sudah mulai mengerti apa yang dimaksudkan dan diinginkan guru dengan menerapkan metode metode mengajar beregu. Sehinng siswa lebih termotivasi untuk lebih aktif dan lebih faham terhadap materi yang dipelajari. Karena hasil belajar belum mencapai harapan, maka dilanjutkan ke siklus III.

Siklus III dilaksanakan hari Kamis, 26 Oktober 2019 pada jam yang sama yakni jam ke-1 sampai jam ke-3 yakni mulai pukul 07.00 sampai 
dengan pukul 08.45 WIB. dengan hasil analisis sebagai berikut:

Tabel 4

Analisis Hasil Belajar Siklus III

\begin{tabular}{llcc}
\hline No & Pencapaian & $\begin{array}{c}\text { Data } \\
\text { Siklus } \\
\text { II }\end{array}$ & $\begin{array}{c}\text { Data } \\
\text { Siklus } \\
\text { III }\end{array}$ \\
\hline 1. & $\begin{array}{l}\text { Rata - rata } \\
\text { Nilai }\end{array}$ & 76,85 & 86,29 \\
2. & 60 & 60 \\
terendah & Nilai \\
tertinggi & 95 & 100 \\
4. $\begin{array}{l}\text { Jumlah } \\
\text { belum tuntas }\end{array}$ & 7 siswa & 3 siswa \\
& $\begin{array}{l}\text { Jumlah } \\
\text { tuntas }\end{array}$ & $\begin{array}{l}20 \\
\text { siswa }\end{array}$ & 24 siswa \\
6. & $\begin{array}{l}\text { Prosentase } \\
\text { belum tuntas }\end{array}$ & $25,92 \%$ & $13,64 \%$ \\
7. & $\begin{array}{l}\text { Prosentase } \\
\text { tuntas }\end{array}$ & $74,08 \%$ & $86,36 \%$ \\
\hline
\end{tabular}

Pada siklus III guru telah menerapkan pendekatan Cooperative model Student Teams Achievement Division (STAD) dengan baik, dilihat dari aktivitas siswa dan hasil belajar siswa, pelaksanaan proses belajar mengajar sudah berjalan dengan sangat baik. Maka tidak diperlukan revisi terlalu banyak, tetapi yang perlu diperhatikan untuk tindakan selanjutnya adalah memaksimalkan dan mepertahankan apa yang telah ada dengan tujuan agar pada pelaksanaan proses belajar mengajar selanjutnya penerapan metode dengan menerapkan pendekatan Cooperative model Student Teams Achievement Division (STAD) dapat meningkatkan proses belajar mengajar sehingga tujuan pembelajaran dapat tercapai. Hasil belajar siswa pada siklus III dengan persentase $86,36 \%$ mengalami ketuntasan belajar, dengan 13,64\% siswa tidak tuntas. Ketuntasan belajar tersebut sudah memenuhi kriteria indikator keberhasilan dengan ketuntasan belajar klasikal yaitu sekurang-kurangnya $75 \%$. maka Penelitian Tindakan Kelas ini diakhiri.

\section{Pembahasan}

Dari hasil analisis pra siklus hasil belajar dikatagorikan belum baik bahkan rendah, karena siswa yang belum tuntas mencapai 59\%. Hal ini disebabkan model pembelajaran yang diterapkan guru kurang tepat sehingga siswa tampak pasif dan kurang antusias dalam pembelajaran. Pembelajran masih berpusat pada guru, siswa tidak aktif dalam belajar. Akibatnya hasil belajar siswa rendah dengan rata-rata 59,81 yakni belum mencapai KKM (75). Dari 27 siswa, jumlah siswa yang tuntas secara individu baru mencapai 11 siswa (41\%) yang lain yakni 16 siswa belum tuntas. Adapun nilai rata-rata yang dicapai 59,81. Setelah diterapkan pendekatan cooperative model Student Teams Achievement Division (STAD) pada pembelajaran PAI materi puasa ramadhan, hasil belajar siswa meningkat dari siklus satu ke siklus berikutnya. Peningkatan hasil belajar tersebut adalah: Pada siklus 1 jumlah siswa yang mencapai KKM masih belum mencapai 75\%. Namun ada peningkatan dari uji pra siklus 11 siswa (41\%) meningkat menjadi 18 siswa $(66,67 \%)$. Kenaikan baru mencapai $25,67 \%$ sedangkan nilai rata-rata 70,15. Angka tersebut juga belum mencapai batas KKM yang ditarjetkan yakni 75 . Pencapaian yang belum maksimal sesuai dengan tarjet. Kriteria ketuntasan tersebut faktor penyebabnya adalah penggunaan pendekatan cooperative model 
Student Teams Achievement Division (STAD). yang diterapkan pada materi puasa ramadhan di kelas VB SD Negeri Gabus 01 belum berjalan sebagaimana mestinya. Maka penerapan pendekatan cooperative metode Student Teams Achievement Division (STAD) perlu disempurnakan pada siklus II.

Hasil belajar siswa setelah dilaksanakan uji kompetensi siklus II, siswa yang tuntas berjumlah 20 siswa $(74,08 \%)$. Sebelumnya pada siklus I berjumlah 18 siswa $(66,67 \%)$ mengalami kenaikan 2 siswa $(7,31 \%)$. Masih belum mencapai ketuntasan yang diharapkan (75\%). Oleh karena itu dilanjutkan ke siklus III . Siswa yag tuntas 24 siswa $(86,36 \%)$. Mengalami peningkatan 4 siswa (7,31\%). Peningkatan ketuntasan hasil belajar siswa kelas VB pada materi puasa ramadhan melalui penerapan pendekatan cooperative model Student Teams Achievement Division (STAD) dari pra siklus, siklus I, siklus II, dan siklus III dapat, dilihat pada tabel dan diagram berikut:

Tabel 5

Analisis Hasil Belajar awal sampai siklus III

\begin{tabular}{clcccc}
\hline No & $\begin{array}{l}\text { Penca } \\
\text { paian }\end{array}$ & $\begin{array}{c}\text { Data } \\
\text { A } \\
\text { wal }\end{array}$ & $\begin{array}{c}\text { Data } \\
\text { Si } \\
\text { klus } \\
\text { I }\end{array}$ & $\begin{array}{c}\text { Data } \\
\text { Si } \\
\text { klus } \\
\text { II }\end{array}$ & $\begin{array}{c}\text { Data } \\
\text { Si } \\
\text { klus } \\
\text { III }\end{array}$ \\
\hline 1. & Rata-rata & 59,8 & 71, & 76 & 86 \\
& & 15 & 85 & 29 \\
2. & $\begin{array}{l}\text { Nilai } \\
\text { terendah }\end{array}$ & 40 & 50 & 60 & 60 \\
3. & Nilai & & & & \\
& tertinggi & 90 & 90 & 95 & 100 \\
& Jumlah & 16 & 9 & 7 & 3 \\
4. & belum & sis & sis & sis & sis \\
& tuntas & wa & wa & wa & wa \\
& & 11 & 18 & 20 & 24 \\
5. & Jumlah & sis & sis & sis & sis \\
& tuntas & wa & wa & wa & wa
\end{tabular}

\begin{tabular}{|c|c|c|c|c|c|}
\hline No & $\begin{array}{l}\text { Penca } \\
\text { paian }\end{array}$ & $\begin{array}{c}\text { Data } \\
\text { A } \\
\text { wal }\end{array}$ & $\begin{array}{c}\text { Data } \\
\text { Si } \\
\text { klus } \\
\text { I }\end{array}$ & $\begin{array}{c}\text { Data } \\
\text { Si } \\
\text { klus } \\
\text { II }\end{array}$ & $\begin{array}{c}\text { Data } \\
\text { Si } \\
\text { klus } \\
\text { III }\end{array}$ \\
\hline 6. & $\begin{array}{l}\text { Prosenta } \\
\text { se belum } \\
\text { tuntas }\end{array}$ & $\begin{array}{l}59 \\
\%\end{array}$ & $\begin{array}{l}13 \\
\%\end{array}$ & $\begin{array}{l}92 \\
\%\end{array}$ & $\begin{array}{c}86, \\
29 \%\end{array}$ \\
\hline 7. & $\begin{array}{l}\text { Prosenta } \\
\text { se tuntas }\end{array}$ & $\begin{array}{l}41 \\
\%\end{array}$ & $\begin{array}{c}66,6 \\
7 \%\end{array}$ & $\begin{array}{c}74,0 \\
8 \%\end{array}$ & $\begin{array}{c}86,3 \\
6 \% \\
\end{array}$ \\
\hline
\end{tabular}

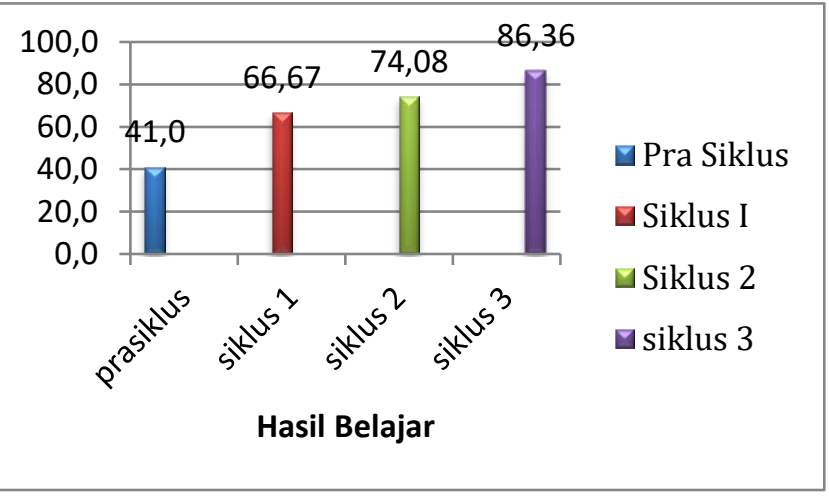

Gambar 2. Prosentase ketuntasan hasil belajar siswa

\section{PENUTUP}

\section{Simpulan}

Berdasarkan penelitian yang telah dilakukan tentang penerapan pendekatan cooperative model Student Teams Achievement Division (STAD) pada pembelajaran PAI materi puasa ramadhan kelas VB SD Negeri Gabus 01 kabupaten Pati dapat disimpulkan bahwa: (a) pemmbelajaran dengan konstruktivistik dengan menerapkan pendekatan cooperative model Student Teams Achievement Division (STAD, memiliki dampak positif dalam meningkatkan hasil belajar siswa yang ditandai dengan peningkatan ketuntasan belajar siswa dalam setiap siklus, yaitu siklus I dengan prosentase ketuntasan $66,67 \%$ dan rata-rata 
kelas 70, 15. Pada siklus II prosentase ketuntasan $74,08 \%$ dan nilai rta-rata kelas 76,85. Pada siklus III prosentase ketuntasan $86,29 \%$ dengan ratarata kelas 86,29. (b) Dengan demikian penerapan pendekatan cooperative model Student Teams Achievement Division (STAD) dapat meningkatkan hasil belajar PAI materi puasa ramadhan pada siswa kelas VB semester I SDN Gabus 01 Kabupaten Pati tahun pelajaran 2019/2020.

\section{Saran}

Adapun sarannya: (a) Guru PAI diharapkan selalu membimbing dan mengarahkan siswa agar gemar bereksplorasi dalam memahami konsep melalui berbagai cara. (b) Adalah hal yang sangat terpuji jika guru selalu mencoba berinovasi dalam mengembangkan bahan ajar dan model pembelajaran dengan berbagai kreatifitas sehingga tercipta pembelajaran yang aktif, kreatif, efekif, dan menyenangkan. (3) Sebaiknya siswa lebih aktif dan termotivasi dalam setiap kegiatan pembelajaran. 


\section{DAFTAR PUSTAKA}

Achmadi. (2005). Islam Sebagai Paradigma Ilmu Pendidikan. Aditya Media

Antika, R. R. (2014). Proses Pembelajaran Berbasis Student Centered Learning. BioKultur, III(1), 251-263. http://journal.unair.ac.id/filerPDF/bk21a95d451ffull.pdf

Arends, R. I. (2008). Learning Tonteach (Terjemahan Belajar untuk Mengajar). Pustaka Pelajar

Arianti. (2019). Peranan Guru dalam Meningkatkan Motivasi Belajar Siswa. DIDAKTIKA: Jurnal Kependidikan, 12, 117-134

Arikunto, S. (2018). Dasar-Dasar Evaluasi Pendidikan (Edisi 3). In Jakarta: Bumi Aksara

Arsyad, A. (2013). Media Pembelajaran. Rajagrafindo Persada

Budiningsih, A. (2005). Belajar dan Pembelajaran. Rineka Cipta

Dalyono, M. (1997). Psikologi Pendidikan. IKIP Semarang

Darmadi, H. (2015). Tugas, Peran, Kompetensi, Dan Tanggung Jawab Menjadi Guru Profesional. Jurnal Edukasia

Habibullah, A. (2012). KOMPETENSI PEDAGOGIK GURU. EDUKASI: Jurnal Penelitian Pendidikan Agama Dan Keagamaan. https://doi.org/10.32729/edukasi.v10i3.169

Kemdikbud. (2003). Agama Islam SD-MI. Balai Pustaka

Lie, A. (2008). Cooperative Learning; Mempraktikkan Cooperative Learning di Ruang ruang Kelas. Grasindo

Majid, A., \& Andriani, D. (2004). Pendidikan Agama Islam Berbasis Kompetensi; Konsep dan Kurikulum 2004. Remaja Rosdakarya

Novita Eka Indiyani, A. L. (2006). Efektivitas Metode Pembelajaran Gotong Royong (Cooperative Learning) Untuk Menurunkan Kecemasan Siswa Dalam Menghadapi Pelajaran Matematika. Jurnal Psikologi Universitas Diponegoro

Saminanto. (2010). Ayo Praktik PTK. RaSAIL Media Group

Slameto. (2003). Belajar dan Faktor Faktor yang Mempengaruhinya. Rineka Cipta

Slavin, R. E. (1980). Cooperative Learning. Review of Educational Research. https://doi.org/10.3102/00346543050002315

Sudjana, N. (2013). Penilaian Hasil Proses Belajar Mengajar. Remaja Rosdakarya

Suprijono, A. (2011). Cooperative Learning; Teori dan Aplikasi Paikem. Pustaka Pelajar

Sutama. (2011). Penelitian Tindakan. CV Cutra Mandiri Utama

Vita, Y. (2014). Metode metode Pembelajaran PAI dan Budi Pekerti (Pendekatan Scientific). Rafi Sarana Perkasa 
Woolfolk, A. E. (2001). Educational Psychology. Allyn and Bacon

Wyk, M. M. van. (2012). The Effects of the STAD-Cooperative Learning Method on Student Achievement, Attitude and Motivation in Economics Education. Journal of Social Sciences. https://doi.org/10.1080/09718923.2012.11893104

Zuhairini. (1983). Metodik Khusus Pendidikan Agama. Usaha Nasional 